\title{
The Life of an XPA-mouse: A Posthumanist Approach to Becoming with Humans in Laboratory and Law
}

\author{
ANNE VAN VEEN \\ Freudenthal Institute, Faculty of Natural Sciences \\ Utrecht University, the Netherlands \\ a.c.vanveen@uu.nl
}

\begin{abstract}
This article is about mice. More specifically about several generations of transgenic mice, XPA-mice, that were born, lived and died in a Dutch laboratory where they were exposed to carcinogens to test if they were more sensitive to these substances than 'regular' mice. Taking a posthumanist approach, I analyze the daily lives of these mice as a multispecies choreography. This choreography involves mice, humans and technologies such as cages, performing together to produce 'the XPA-mouse' as laboratory mouse. The focus is on daily doings and bodily entanglement, rather than linguistics, making it more inclusive of human bodies, nonhuman animals and materials. However, for the different phrases of this choreography, I do not only discuss what is included but also which moves have been foreclosed, which worlds and accompanying mouse response-abilities have been excluded? This focus on exclusion will show how interspecies power relations both within the lab and within social and legal discourse have greatly constrained the meaning of agency for these particular mice.
\end{abstract}

KEYWORDS: mice; posthumanism; choreography; animal experimentation; ethics 


\section{Introduction}

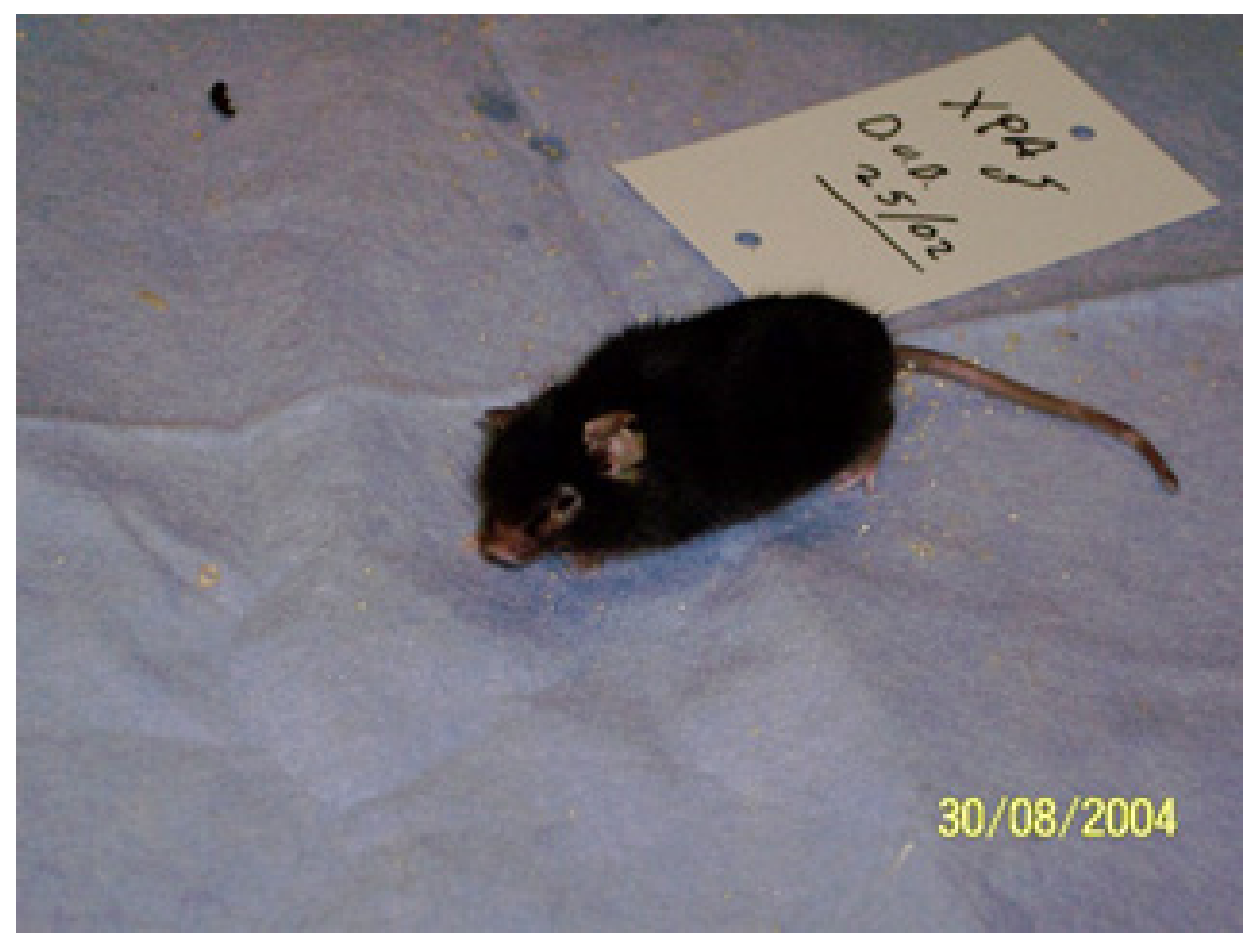

Figure 1: An XPA-mouse

This article is about mice. More specifically about several generations of transgenic mice, XPA-mice, that were born, lived and died in the laboratory of the National Institute of Public Health and Environment (RIVM) in Bilthoven, the Netherlands during the 1990s and 2000s. They were exposed to carcinogens to test if they were more sensitive to these substances than 'regular' mice. ${ }^{1}$ The XPA-mouse in the picture is six months and five days old. If you look closely at her left ear, you can see that a few pieces of ear have been cut away. This was done so she could be told apart from other mice living in the same cage.

I have chosen to open with this picture, to immediately draw your attention to this mouse as an embodied individual. Mice and other nonhuman animals that are tested on in laboratories, are often written about in aggregated numbers or reduced to genetic characteristics of their strain (Birke et al. 2004; Davies 2013; Rader 2004). Although there has been more attention for nonhuman animals in history recently, they

1 XPA-mice are deficient in Nucleotide Excision Repair (NER), an important form of DNA repair. This makes them more prone to develop tumors after exposure to carcinogens (De Vries 1997). 
generally do not take center stage (Benson 2011; Guerrini 2016; Ritvo 2002; Woods 2017).

Within other areas of research, useful work has been done to move beyond anthropocentrism from which historians can draw inspiration. Posthumanism aims to decenter the human and provides analytical concepts to rethink animal experimentation to include more than human agencies and response-abilities, showing how both humans and non-humans are co-constituted in interactions (Greenhough \& Roe 2019; see Twine 2010a; Wolfe 2009 on posthumanism in general). Within STS scholarship, care has become a central concept in researching animal experimentation. This has shown how care is material, relational and performative, not opposed to instrumentality or domination and that it plays a crucial role in scientific knowledge production (Davies et al. 2018; Druglitrø 2018; Friese \& Latimer 2019).

In this article I aim to show how historical case studies, such as that of the XPAmice, can benefit from a focus on multispecies entanglement, by analyzing the daily practices of XPA-mouse breeding and experimentation and following these mice from the first to the last one that lived at the RIVM. ${ }^{2}$ At the same time, writing animal histories such as this that radically decenter the human will enable us to, in the words of historian Anita Guerrini $(2016,26)$, 'deconstruct the animal-human divide and begin to write a new history that can underpin a new ethics for the Anthropocene.'. To achieve this, we need to look not only at entanglement in the lab, but also beyond at interspecies power relations and what these meant for the XPA-mice. Therefore, I will focus not only on XPA-mice becomings in the lab, but also on XPA mice becomings in laws and regulations. As a theoretical framework of analysis, I turn to posthumanist approaches as proposed by Hollin et al. (2017) Birke et al. (2004), both of which are an elaboration on the work of Karen Barad on posthumanist performativity. Both experimentation and regulation practices are analyzed as boundary making practices, producing agential cuts that allow certain XPA-mouse worlds to become and foreclose others. ${ }^{3}$ These cuts are analyzed to answer the main question of this paper: which response-abilities were included for the XPA-mice in the multispecies world of the laboratory as well as in the

2 The descriptions of these daily practices are based on interviews, images, and archival materials such as lab journals and ethical review applications. Interviews were held with six people who worked with the XPA-mice, as scientists, ATs and lab analysts. They are referred to as A1 (AT), L1 (lab analyst) and S1-4 (scientists) to preserve their anonymity. The pictures in this paper were also provided by them. Archival materials are all from the RIVM archives.

3 Agential cuts are ontological separations, "one part of the universe making itself intelligible to another part". This is an ongoing process of iterative materialization and not a cut existing in a pre-determined reality (Barad 2007, 176). 
domain of law and which manifestations of agency have been foreclosed?

The structure of the paper is as follows: I start with my theoretical framework (section 2). Then I will describe how XPA-mice came to exist and the subsequent choreographies of breeding and experimentation (section 3). In section 4 , I analyze how regulations and power relations have affected XPA-mouse response-abilities on both micro and macro level. From there, I argue that a radical posthumanist ethics requires a remaking of experimental practices and regulations that go beyond the welfare reforms often proposed from a care ethics perspective. For ideas of how such a remaking could look in practice, I finally turn to the 'political turn' in animal studies, and suggest that nonhuman animals should not only be seen as actors in scientific knowledge production, but also be included as political actors.

\section{Theoretical framework}

\subsection{Entanglement and exclusions}

STS studies on animal experimentation focus strongly on care and multispecies entanglement, foregrounding both human and nonhuman animals as embodied agents. Building on the influential work of Donna Haraway, both humans and animals are seen as 'response-able', and this capacity is by definition relational, always implicating multiple beings becoming intra-actively (Haraway 2008). This approach has yielded a deeper understanding of the roles of daily, non-standardizable interactions between humans and non-humans in experimental practices. It has also shown the important role of animal technicians (ATs) in creating a culture of care and putting welfare regulations into practice, changing both themselves and the nonhuman animals they care for (Greenhough \& Roe 2018). Several scholars have argued however, that a too narrow focus on multispecies entanglement lacks attention to power relations and to how care and welfare are used to facilitate or legitimize continued oppressive relations such as animal experimentation (Giraud \& Hollin 2016; Greenhough \& Roe 2019; Poort et al. 2013; Twine 2010b). Haraway for example is often criticized for arguing that animal experimentation should be done 'responsibly', rather than challenging the underlying power inequality (Adams \& Donovan 2007). While in care studies a constraining wider context is often acknowledged, it generally is not given much attention in analyzing practices, since the focus is on cross-species entanglement. To include more than entanglement, I turn to the work of Hollin et al. (2017).

Hollin et al. (2017) discuss Karen Barad's work on posthumanist performativity, and 
specifically her concept of agential realism, in relation to Science and Technology Studies. At the end of their article, they argue that the 'radical potential' of agential realism is often missed, because scholars taking up Barad's approach focus too much on questions of entanglement and not enough on questions of exclusion (Hollin et al. 2017, 932). Like other scholars, Barad foregrounds entanglement, nonhuman agency, and reality as performed, rather than pre-existing interactions. And like in many other posthumanist and STS approaches, dualisms such as human/animal, nature/culture and object/subject are challenged. However, according to Hollin et al. Barad's posthumanism goes further than this:

The ethical significance of agential realism, therefore, is not just in extending the idea that things 'could have been otherwise' to the ontological realm, but in conceptualizing the precise moments at which things congeal 'as they are' by understanding the processes through which particular material properties emerge and other realities are excluded from being. (Hollin et al. 2017, 933)

This process of congealment is vital, it means that worlds that did become are relatively stable and cuts made can often not be reversed, implying that accountability is required, not only for intra-actions that are included, but also for possible worlds that are excluded. Such an approach can reveal that "(...) certain responsibilities and manifestations of agency could have already been foreclosed by a succession of cuts." (935). For the situation of animal experimentation, this would mean not only accounting for what happens in the laboratory, the bodily entanglement of humans and XPA-mice in the case at hand here, but also for worlds that did not become (e.g. a world in which these mice are not tested upon).

In their article Animal Performances, Birke et al. (2004) engage with Barad's posthumanist performativity to look at dyads of human and nonhuman animals. Specifically, they consider the dyad lab rat and scientist. Laboratory rats and scientists are not seen to pre-exist the practice of animal testing, rather they emerge out of a choreography involving rats, humans and technologies, as hybrid phenomena. Intraactions that make up this choreography can reproduce as well as challenge a human/ animal dichotomy, showing how this dichotomy is not 'natural' or pre-given. At the same time, this dichotomy can become relatively stable through an iterative process of congealment and consequences for individual lab animals can be irreversible.

According to Birke et al. this performative approach is more inclusive of nonhuman animals, as it allows for nonhuman agency and because it is not focused 
on language, but on doings. Nonhuman animals are seen as active participants whose behavior matters. Performativity also allows for an analysis of the workings of power as part of the choreography. Birke et al. emphasize how 'animality' is complex and constructed, just like gender and humanity. It is a relational concept that is performed, not in an isolated choreography, but in relation to socio-cultural power relations.

Including socio-cultural power relations in the analysis is vital for understanding nonhumans as agents in a context that is highly asymmetrical with respect to interspecies power hierarchies. XPA-mice were active participants in the becoming of the 'laboratory mice', however this does not mean that they were somehow volunteering, or collaborating in their instrumental use, their active participation does not make their being instrumentally used by humans non-oppressive. It does imply that humans are not in complete control over materializations as they are not in complete control over all of the co-constitutive elements from which the 'lab mice' hybrid emerges.

Regulations play an important role in making worlds that did become more stable, for example when certain animal experiments become regulatorily required, making it more difficult to change these practices. Legal practices are not only important in the sense that they intra-act with the laboratory choreography, but also as a potential space for nonhuman agency on the macro-level. We can analyze the making and enactments of experimentation laws as a boundary making practices as well, to see if there has been any possibility for XPA-mouse agency on that level and to think about how regulatory practices could be remade less anthropocentrically in the future.

\subsection{Power, macro-agency and the political turn}

The 'political turn' in animal studies, though characterized differently by different scholars, concerns itself with applying political theory to interspecies relations and ethics (Kymlicka 2017; Meijer 2016; Millegan 2015; Wyckoff 2016). The political turn is not so much concerned with (the ethics of) interaction between individuals of different species, but with the "(...) moral dimensions of the social and political contexts that structure interactions between humans and nonhuman animals." (Wyckoff 2016, 236). If we look at these larger dimensions, we can then also ask if there was any possibility for manifestation of XPA-mouse agency in the area of the law itself.

In her work on interspecies democracies, Eva Meijer (2016) makes a helpful distinction between micro- and macro-agency and emphasizes the importance of considering both: "(...), if we only focus on micro-agency, the subordinate position of animals is not challenged. Because of human dominance, currently they cannot 
make decisions concerning the larger dimensions of their lives (...)." (66). Examining XPA-mouse response-abilities on both the micro and macro level, will take us further in understanding and accounting for potential worlds that have been foreclosed for them. Political philosophy is also helpful in making the step from rethinking to remaking interspecies relations and experimental practices. While posthumanist scholarship has provided useful tools for theoretical analysis, it tends to be not very pragmatic. Political scientists in contrast, tend to have a more pragmatic approach, making concrete suggestions for how to change political and regulatory practices.

\section{XPA-mice becomings in the Lab}

Following the successful creation of the first XPA-mice in 1994, thousands of XPA mice were bred at the animal research center of the RIVM for internal use in experiments and distribution to other research facilities. In this section I focus on the XPA-choreography: the intra-actions of mice, humans and technologies involved in the becoming of the XPA-mice as laboratory mice. ${ }^{4}$

\section{Act 1: Mice breeding}

Writing about rat-human choreographies in the laboratory, Birke et al. argue that:

The rat itself is an agent in the process, whether it obligingly reproduces to order or squeals and bites the experimenter. So too are the technologies (cages, etc.) which produce and are produced by ratsin-laboratories. Indeed, what we understand as 'the laboratory rat' is something of a hybrid, constituted jointly by the animal, the people and various associated technologies (standard cages; devices for weighing or killing; food-stuffs and so on: see Birke and Michael, 1997). In that sense, 'laboratoryratness' is a part performed to fit very precisely into the scientific enterprise; meanings emerge from a nexus of apparatuses, animals and people. $(2014,173)$

Following this approach, we can see how out of the XPA breeding choreography, a specific type of laboratory hybrid emerged: the 'breeding mouse'. Alongside it emerged the 'human breeding technician' and the 'breeding room', all co-constituted by mice,

4 Please be aware of the historical nature of the procedures described and that they may differ from current practices. 
humans and non-living materials and technologies. Cages were a key part of this, as well as breeding technologies. Both were geared towards making the breeding process as efficient as possible.

Humans held the XPA-mice in cages to prevent them from leaving. This may seem too obvious to even mention, but let us pause for a second and consider what a cage does. A cage first of all controls the space you can and cannot be in, who you can and cannot have contact with inside the cage. Beings you share the cage with or who have access to it cannot be avoided. The location and physical characteristics of the cage determine what you can observe and who you can contact outside of the cage and vice versa. A cage is also a constant reminder of the liveliness of these mice, dead mice or non-living materials do not need to be confined. The picture below shows a typical layout of one of the several animal rooms at the XPA-mouse breeding facility.

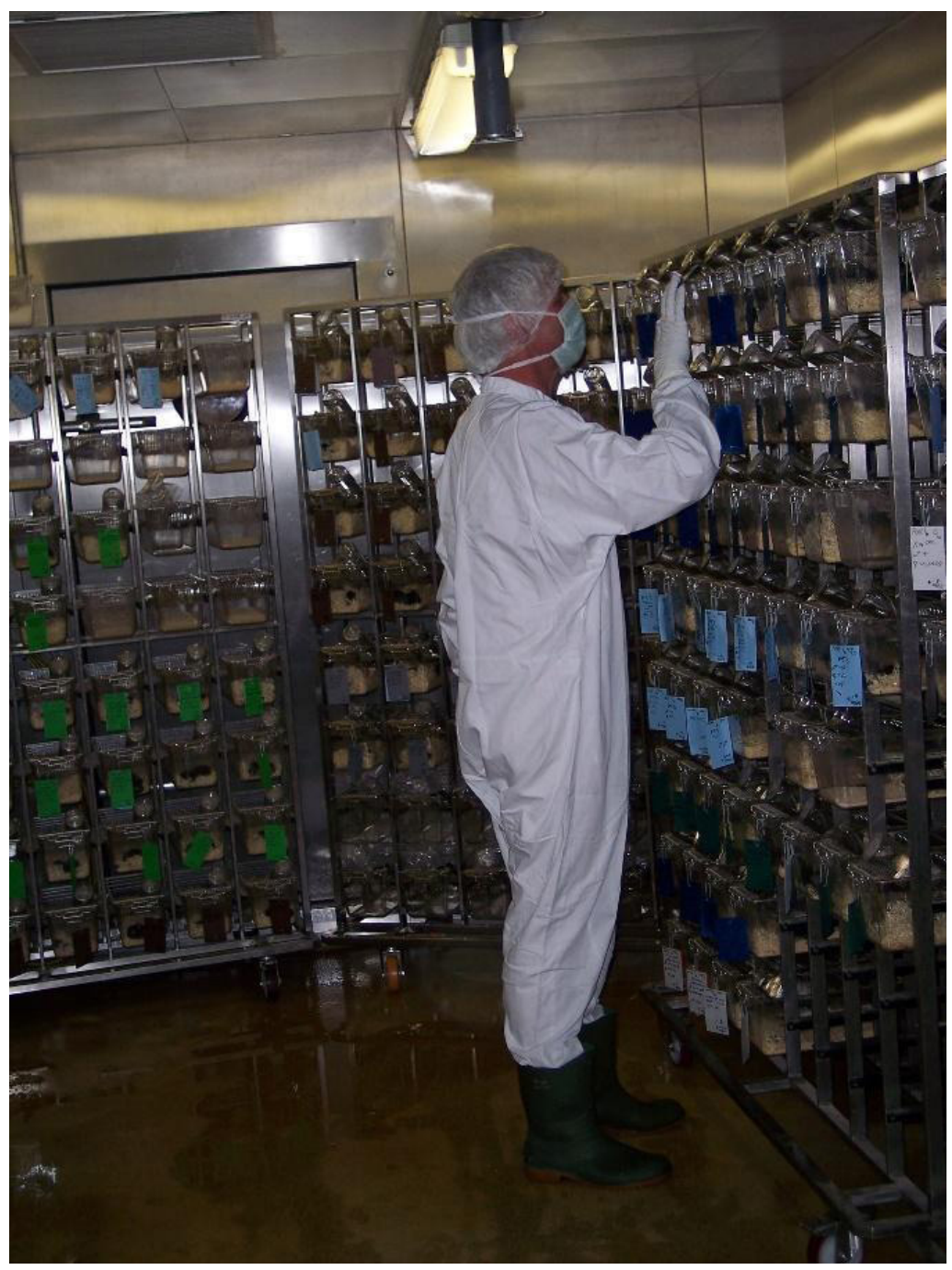

Figure 2: Animal Breeding Room 
Cages were stacked eight high in purpose-made shelves, placed alongside the walls of the animal room. The cages are placed in such a way that the humans have easy access to all the mice and good visibility of all the cages, so they can do their work efficiently.

For cleaning purposes, mice were picked up and temporarily placed in a different cage regularly, and then put back again into their cleaned cage. For efficiency reasons, ATs picked up a 'bunch' of mice at a time, thus involving not only a touching of human and mouse, but also several mouse bodies being squeezed together (A1). These moments of 'handling' the mice were mentioned as the moment when mice are most likely to bite: "But the lab mice here, yes I have been bitten, but that was more your own clumsiness. And if you grab one too tight or the wrong way, then it is logical that he wants to defend himself" (A1). Not only is the mouse here recognized as active, as someone who can dislike and bite, but in addition the, agentic capacity to 'act with a goal in mind' (i.e. biting to defend) is attributed to the mouse. This biting mouse challenges her status as object and can teach the human to be more careful in handling mice in the future, both mice and human adapting their bodily responses together. If we focus narrowly on this bodily entanglement included in the XPA-choreography, this might lead us to think of 'handling' as a mouse-human 'collaboration'. By such a narrow focus however, we miss all the response-abilities foreclosed for the mice (e.g. leaving the laboratory).

The type and size of the cage used was determined by the interaction of: a human quest for efficiency, mice mating and maternal care behavior, dimensions of the animal rooms and available cages, and animal welfare regulations. According to the AT responsible for breeding the XPA-mice, breeding was all about achieving 'minimal stable space, maximum production per woman'(A1). ${ }^{5}$ As he explained, breeding efficiency was measured using the Production Efficiency Index (PEI), defined as average offspring per female per week. A mouse line with a PEI of 1.9 was considered a well breeding line. This PEl is influenced by mice behavior, such as maternal care (i.e. better maternal care means more surviving babies), which is in turn influenced by cage size.

In the picture below, four types of cages are shown, from top to bottom: type 1-elongated, type 2, type 3 and type 4 .

5 This quote is from a powerpoint presentation the AT used when giving a presentation to colleagues on breeding mice and showed to me during the interview. The Dutch term vrouw is translated as woman here, as that is the most common translation. It could also be translated as 'female', but nonhuman females are generally referred to as vrouwtje in Dutch. 


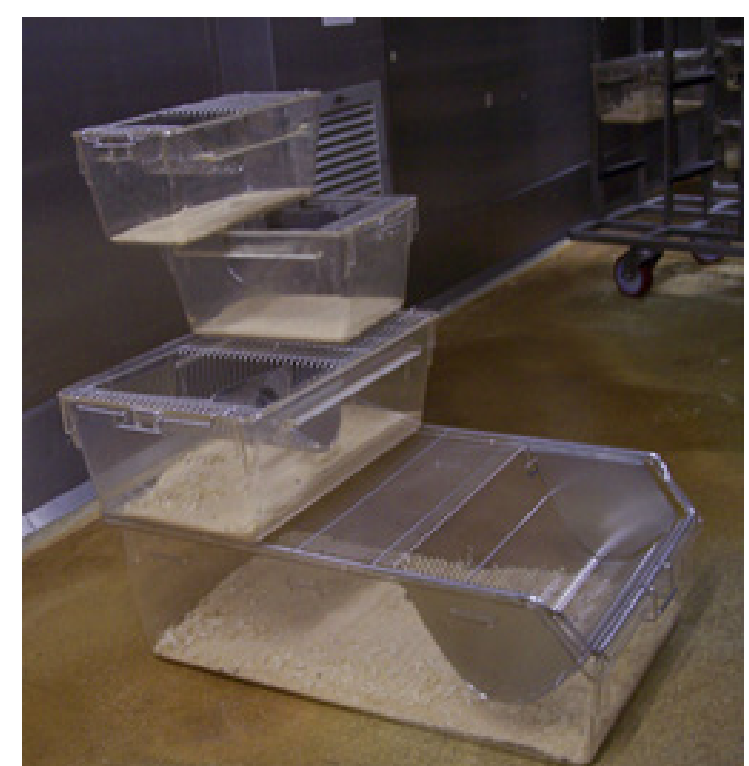

Figure 3: four types of cages
In a breeding efficiency study, it was found that mice PEl is higher in cage type 2 , where the mice have more space than in type 1-elongated. But because type 1-elongated is narrower than type 2 , it is possible to fit more type 1-elongated than type 2 cages into the same animal room. Therefore, XPA mice were living in type 1-elongated cages during the breeding process. The regular type-1 cage could not be used as animal welfare regulation had deemed it too small. Regulations also stipulated that the cages be 'enriched' with bedding and nesting material. According to $A 1$, not all lines of

mice do something with the nesting material, but XPA-mice create a 'nice little nest'. The enrichment of cages was seen as beneficial for both mice and the experiment, as less stressed mice made better research instruments. In providing enrichment, the ATs searched for a type of enrichment that suited a specific strain of mice (A1). In doing so, they went beyond what was stipulated in welfare regulations, something that is commonly found in studies of AT's and experimental animals (Friese \& Latimer 2019; Greenhough \& Roe 2019; Kirk 2018).

The 'breeding system' also focused on efficiency. A male and female mouse lived together $24 / 7$ in the same cage; a system called permanent meeting breeding. When a female mouse gave birth, the baby mice stayed in the same cage for about 18 to 20 days. The picture above shows such a mouse family together in a type-1-elongated cage. The permanent meeting system had the 'advantage' of making use of the female mouse's postpartum estrus. After giving birth, she is fertile for 12-24 hours. If the male mouse is in the same cage the whole time, the female mouse can become pregnant again,

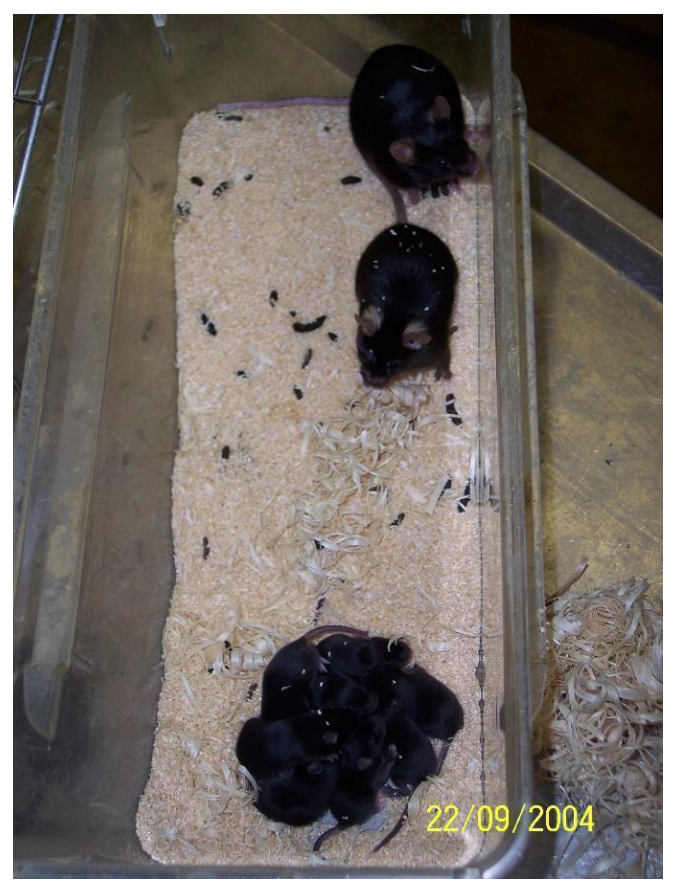

Figure 4: A mouse family in a cage 
immediately after giving birth. As implantation is slightly delayed in nursing mice, the next litter is born after 21-22 days, just after the previous litter has been weaned. So if all went according to human plans, female mice were pregnant almost constantly. A female mouse was put in a breeding cage with a male mouse at about ten weeks of age. After six months or so, they start to 'produce' less babies and humans kill them. The male mice can be used for 'two rounds' of breeding and because the XPA line is an inbred mouse line, the male mice can be paired with their own daughters (A1).

The XPA-breeding choreography as described so far, involved many intimate mouse-mouse interactions: intercourse, giving birth, nursing babies, siblings huddling together (as can be seen in figure 4). Here, we can catch a glimpse of other becomings of these mice: partners, mothers and fathers, warm bodies to lie against. This reminds us that these mice create their own meaning in relation to one another. For the mice to become research materials, intra-actions with humans and technologies are required, it is not something they are in some essential way, hence the hybrid Birke et al. speak of. It also requires a socio-cultural context in which mice are 'breedable' and 'killable', a context which forecloses many possible worlds for the XPA-mice that were bred to be research animals.

Of all the XPA-mice born in the breeding facility, only the ones with genotype -/- were used in experiments. To find the mice with the desired genotype, they were genotyped. This was done by cutting of a piece of the tail, which was sent to the lab for

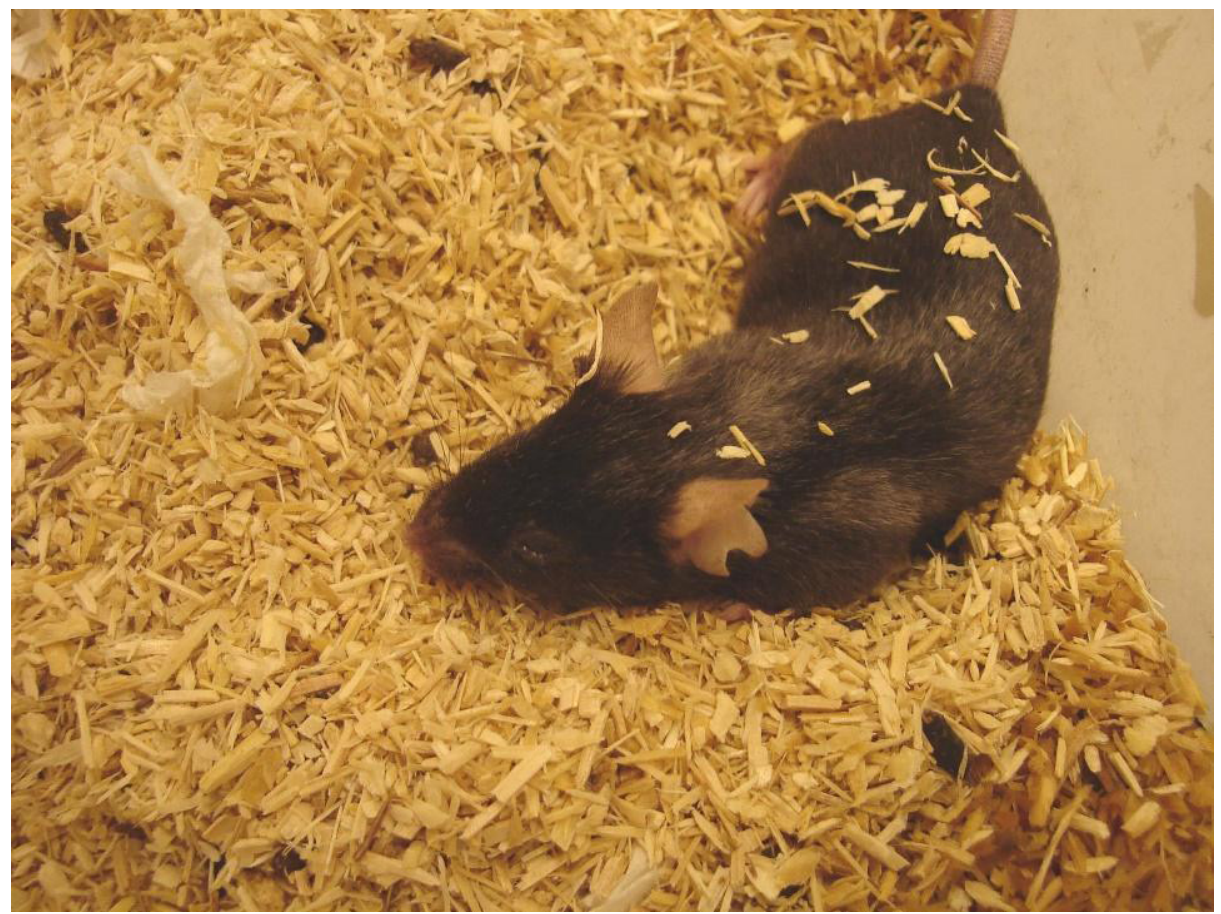

Figure 5: A mouse with ear cuts 
determining the genotype. For identification purposes, cuts were made in the ear(s) of a mice (see figure 5) for example: mouse five has one ear clip in the left ear and two in the right. This was not a standardized system, but dependent on the AT who had made the cuts. Once the mice had been genotyped, the ones with the 'right' genotypes were ready to be sent off for use in experiments. The other mice were killed.

L1 has witnessed many of these genotyping procedures and recalls the age of the mice making a lot of difference:

If you do it quickly and at a young age, very little blood is involved. But if the animals are too old, then it does get bloody, they will have a drop of blood and then you let them go and they will go through the whole cage and touch all the walls and the whole cage will be red, that is really gross and they will need a new cage as well. But it closes rather quickly, or they squeeze it close or push it in the sawdust to close it.

The ear-cutting experience depended on the number of ear cuts received and on the skill of the AT:

Some would go cut cut cut cut and in no time they would have 3 cuts in one ear, while others tried it as well and the mouse would have no ear left as a manner of speaking. It was just really difficult and they would prefer not to give 3 cuts in one ear. (L1)

S1 compared ear cuts to toe clips (which was not practiced at the RIVM, but common practice in other labs). When asked whether ear cuts were less painful, she found it difficult to judge the amount of suffering involved for the mice:

\begin{abstract}
I am not sure, you see, if you cut, the little mouth opening and a squeak, although difficult to hear in the isolator. I also worked in an animal room without isolator and then you hear them squeak, but that can also be stress from being picked up. It is always difficult to say, they must feel something, that is for sure. Yes, the ear cut was also not nice, because they did that with the same scissors [as the tail], so it would be one cut and a second and a little corner would be cut out. There were also people who preferred a tong, like a perforator for belts, but many times smaller of course. People tried to cut at the edge of the mouse ear and then it would be done with one cut. People had their preferences.
\end{abstract}

These narratives point towards the situatedness of the experiences of care and suffering; even within one laboratory individual experiences of the common practice of 
tailing and ear clipping can vary greatly, depending on the mice-human duo involved. Not only the age of the mouse, but also the bodily adaptation of the human to the practice of ear clipping affected mouse suffering. The older mice, bleeding as a result of the tailing, responded by running frantically through the cage, against the walls. While this behavior likely did little to alleviate the suffering, it does indicate to attentive humans that the tailing is painful, thereby challenging the mouse's object status, bringing attention to their liveliness instead. The human can respond by learning to execute these movements less painfully, or to ask someone more skilled to perform them. Responses that are excluded from the breeding choreography, are those that involve not tailing the mice. Not only would this go against protocol, it is simply not conceived of as an option; sacrificing the experiment rather than the mice would go against social-cultural power relations. Genotyping was a determining moment for mice, as their (reduction to) genotype and human valuation thereof decided their fate as either 'mouse killed in stock' or part of the 'lab mouse' hybrid.

\section{Act 2: The experiments}

After the first XPA-mice were created, experiments were done to test their increased sensitivity to carcinogens. In 1996, XPA-mice became part of the international Alternatives for Carcinogenicity Testing (ACT) program. ${ }^{6}$ In this program that sought an alternative for the chronic mouse bio-assay, 21 substances were tested on five TGmouse models, a neonatal mouse model and an in vitro Syrian hamster embryo assay. At the RIVM, the experimental choreography started with mice moving away from their parents and from the breeding facility to the experimental facility. ${ }^{7}$ Scientists ordered mice from the breeding facility, who then arrived in boxes at the experimental location. There they were separated from their siblings when assigned randomly to experimental and control groups (S1, S2). Male and female mice lived separate from one another, meaning that mating, pregnancy and babies were not in their future. While according to respondents, duo or group housing was always preferred, archives show that mice were also housed individually in some experiments. For example, in a six-month oral carcinogenicity study with Cyclosporin A, 342 mice were housed

6 ACT was initiated and coordinated by the International Life Science Institute (ILSI) and the Health and Environmental Science Institute (HESI) in the US, in collaboration with the Central Institute for Experimental Animals (CIEA) in Japan and a European working group led by the RIVM.

7 I focus on the carcinogenicity experiments that these XPA-mice were part of. They have also been used in other types of experiments, mainly basic research about ageing. 
individually. ${ }^{8}$ The responses to the new living arrangements varied between mice. Female mice generally had no problem living together in one cage, but male mice sharing a cage could sometimes become aggressive towards one another. Humans responded to this aggression by separating the mice. The aggressive mouse behavior affected not only their own living situation, but in certain experiments also the study in ways relevant to humans. Aggressive mouse behavior could make it more difficult to determine research results in skin cancer studies, as it was not always clear if skin damage was the result of mice fighting or of the experiment (S1). Because of this maleon-male aggression, in some studies, females were housed together whilst males lived individually from the start. The behavior of some male mice, in that way, also affected the living situation of future mice, who were not given the opportunity to be aggressive towards a cage mate anymore.

During the carcinogenicity experiments, mouse-human intra-action consisted mostly of handling the mice to clean the cages and exposing mice to test substances. XPA mice were exposed to either carcinogens or non-carcinogens during either six or nine months. ${ }^{9}$ Exposure happened in several ways: UV-light exposure (figure 6), rubbing a substance on the skin, force feeding (gavage) or mixing a substance in the food.

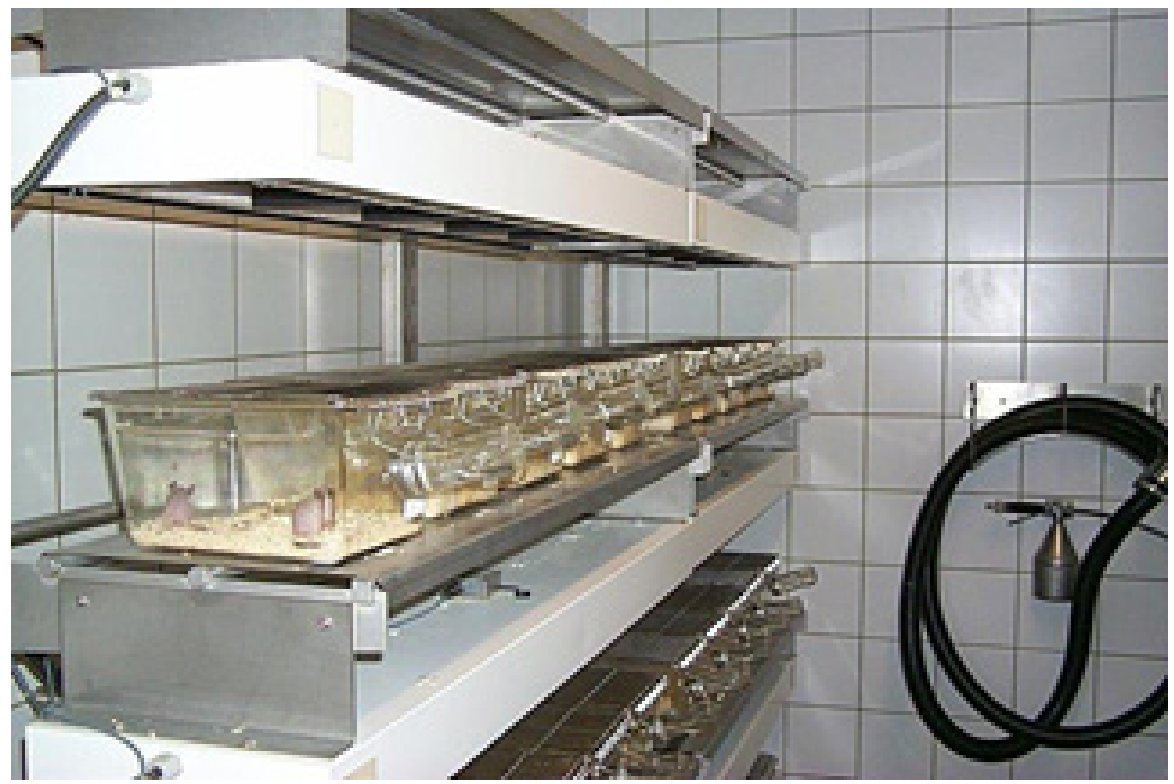

Figure 6: Mice being exposed to UVB

8 Six months oral carcinogenicity study with Cyclosporin A in XPA -/- mice by R. Beems, 2 June 1998, file no. 650080/9800518, RIVM Archives, Bilthoven, The Netherlands

9 The experiments on XPA-mice involved exposing them to a variety of compounds: UVB, DMBA, B[a]P, Cyclosporin A, Phenacetin, Resperine, D-mannitol, PhIP, p-cresidine, 2-AAF (Van Kreijl et al. 2001). 
The mice that were part of the skin exposure studies were shaved on a weekly basis. All the mice were checked regularly for tumors or other signs of illness. After the exposure period, the mice were taken to the pathologist to be killed and their tissues analyzed.

During the experiments, suffering was caused by both the treatment received (compound exposure), the effects of the treatment, as well as illness unrelated to the experiment. Gavage exposure was mentioned by most of the respondents when the issue of suffering was brought up. With gavage feeding, mice have a tube inserted via their mouth into their stomach through which they are force fed the compound dissolved in oil. It was obvious to the respondents that the mice did not like the gavage feedings, some making comparisons to how it would be for humans: "And especially the gavage they did not like, you as a human are also not like some kind of goose(...)" (S1) and in response to the question "Do you think gavage entails suffering?": "Yes, if I grab you and get a big syringe and fill your stomach with stuff, you do not enjoy it, not even if I sedate you." (S2). One respondent also noticed how mice adapted their response to the gavage feeding over time:

Gavage studies, that was in the early days, they also did not like that. But they would get used to that. That is also what the caretakers would say, it was in a manner of saying like, "well let's do this" with their mouth already open and, well shove it in and get it over with. Of course it was not really like that, but they got used to it and accepted it, got easier over time. (L1)

In later studies gavage feeding was often replaced by exposure through food, which was seen as not causing any suffering, apart from sometimes the mice not liking the taste of the food too much (L1, S1, S2). While it was sometimes unclear what suffering means for a mouse, in certain situation it was obvious to observing humans that the mice experienced pain. A treatment that caused such a noticeable reaction of suffering was exposure by injection and especially intraperitoneal (IP) injections:

Suffering? Yes well, the injections of course, we have also done IP injections, they are supposedly not nice. You can also see that by the animal's behavior: they would huddle in a corner for a while, you would really notice that. (L1)

The first exposure studies done with the XPA mouse were done with UV-B and DMBA. Although the exposure itself was not mentioned to be painful, these compounds had 
some more acute effects than other exposure routes causing not only tumors, but also irritation of the skin. These were looked for during clinical inspection of the mice and written down in a check-in list. In the DMBA check-in list of September 1994, one of the entries reads: inflammation, tumor front leg, bad condition, red skin, and scabs. ${ }^{10}$ In the same month, an interim section and histopathology of the killed mice were performed because of a severe skin reaction after two exposures to DMBA. ${ }^{11}$

Sometimes, effects of exposure were unexpected. In the first study with PhiP, XPA mice who received the highest dose were in such a bad condition after a few weeks that they either died or were so ill that they had to be removed from the experiment. ${ }^{12}$ The study was then redesigned with lower doses.

The development of tumors was another type of suffering obvious to the respondents: "When a mouse gets a tumor that bothers him of course." (S2). Here certain behavior of the mouse was also seen as a sign of suffering: "And sometimes it was really sad, then they would have a big tumor and crawl away into a corner, that is what you see." (L1). When it came to tumors, measures were taken to make sure the mice did not suffer more than was necessary for the experiment.

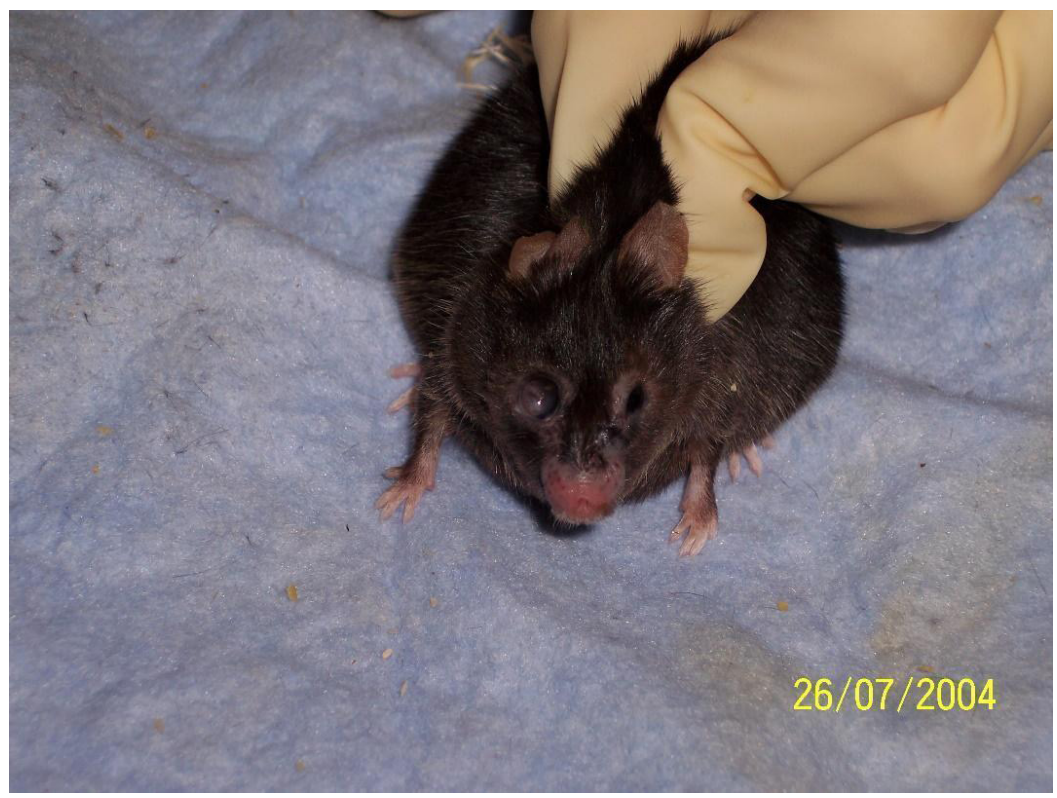

Figure 7: Mouse with eye pathology

10 Check-in lijst klinische bewaking, September 1994, File no. 4885 APG LCM 94 73: XPAC knockout DMBA, RIVM Archives, Bilthoven, The Netherlands

11 Dr. P.W. Wester, Uitslag histopathologie interimsectie (1994), File no. APG-LCM 94-73: XPAC knockout DMBA, RIVM Archives, Bilthoven, The Netherlands

12 R.B. Beems, Carcinogenicity of PhIP in XPA -/- mice: korte rapportage pathologie, 26 March 1998, file no.: 199600363, RIVM Archives, Bilthoven, The Netherlands 
And you know skin cancer you see and then we would have the vet there and beyond a certain set tumor size, they would get euthanized. With other tumors, you do not see it, there was a lot of control, I remember they would check the skin of the neck, if it would stay up, then we would euthanize. We were not in it for very ill animals, not relevant (S1).

The success of practicing humane endpoints was seen to depend on the ability of humans to read a mouse's health status: “(...) weak, ill animals were put down, the pathologist I worked with, he could read and write with those animals and A1 was also on top of it (...)." (S4).

Care practices such as cage enrichment and humane endpoints required bodily attunement of human bodies to mice bodies, emphasizing how both mice and human bodies are co-constituted in this multispecies choreography (see Greenhough and Roe 2018 on the role of attunement in the relation between ATs and experimental animals). Several non-AT respondents mentioned how AT's really care about the animals and take good care of them. Attention to welfare and acts of care, even if not (just) instrumental in conducting the experiments, in that way also helped to facilitate experimental practices, because they helped to make experimentation acceptable as 'good science' (Druglitrø 2018).

Research by Arluke (1988) has shown how symbolic and psychological measures can facilitate animal experimentation, because they help people deal with the psychological demands of a job that requires both caring for and objectifying nonhuman animals. L1 talks about this tension between XPA-mice as materials and as living beings: "After a while, you start hoping for tumors, hoping for them to get symptoms quickly. But then you also realize that you are thinking about a living being that you are sacrificing. We were aware of that.". She also described how one of the pathologists dealt with this tension by thanking a mouse he had just sacrificed in the name of science. Of course, using terminology such as sacrificing and 'removing' instead of killing also serves to ease the tension.

The narratives of care and suffering bring various forms of suffering, response abilities and attributions of agency to our attention, all functioning as micro-challenges to the object status of nonhuman animals and animal/human dichotomy. ${ }^{13}$ The mice's

13 According to Irvine (2001), play between human and nonhuman animals can be seen as micro-challenges to a human/animal dichotomy as play “(...) honors animals' subjectivity and communication skills, making this everyday activity an act of individualized resistance to human disregard for non-human life" (1). In a similar vein, mice biting humans when they do not want to 
opportunities to mitigate or avoid suffering meanwhile were virtually non-existent. One instance that could be seen as such would be that of a mice 'learning' that gavage feeding is less unpleasant when being cooperative. Considering this human/mouse entanglement in gavage-feeding here we must again be mindful of what is excluded for these mice (from not being gavage fed to not being part of any experiment at all). In most cases, the only responses available where those that indicate but do not alleviate suffering (e.g. biting, huddling in a corner). The refinement measures taken by humans and their responses to mouse suffering were limited as well, given that the best possible response to a sick mouse, was killing and thanking her and the best possible response to a mouse trapped in a cage, was giving her some sawdust.

Acts of care were certainly an important part of XPA-mice and RIVM-human relations. Overall however, the 'laboratoryness' and object status remained very stable as it was continuously reproduced in every act tailing, ear-clipping, caging, exposing, handling and finally killing (acts that were maybe done with care, but not out of care). As Birke et al. and Hollins et al. emphasize, this iterative congealing process is important. It is where emerging worlds become relatively stable and the exclusion of other becomings difficult to reverse. These daily laboratory doings intra-act with sociocultural power relations and legal practices however, which are considered next.

\section{XPA-mice becomings in the Law}

In this section, I first look at how legal practices and species power relations in general intra-acted with the laboratory choreography to constrain possibilities for XPA-mouse micro-agency. Then I analyze mouse agency on the macro level: were they able to affect the legal and political dimensions of their lives? Finally, I venture into the rather speculative realm of how we can make animal testing law non-anthropocentrically.

\subsection{Micro-agency}

In the Netherlands, the first law on animal testing was accepted in 1977 and enacted in 1980. This law states that animal testing is only allowed when no non-animal test is available and when the interest in the test outweighs the suffering of tested animals. 'Animals' in this legal context means 'nonhuman vertebrates and cephalopods. ${ }^{14}$ As

be held can also be seen as such a micro-challenge in which mice try to resist human domination over their lives, asserting themselves as subjects rather than objects.

14 Overheid.nl, http://wetten.overheid.nl/BWBR0003081/2018-01-13 (visited 10. 9. 2018) 
in other European countries, the 3Rs were the dominant framework for looking at animal testing in the Netherlands in the 1990s when the XPA-mouse experiments were conducted (Pijnappel 2016; Schiffelers 2016). In 1996, permission from an Animal Experimental Committee (AEC) became obligatory. In the AEC applications written for the experiments with the XPA-mice, the 3 Rs discourse is clearly visible. ${ }^{15}$ Respondents also referred to the $3 \mathrm{Rs}$ :

\begin{abstract}
We always had the same justification for the experiment, you want a test that is bearable for those animals, because it is shorter, also it is cheaper. In the normal test, you would have 2 species and fifty animals per sex and dose, 800 in total if you succeed right away and it takes two years. We only used fifteen [per group], huge reduction, it is both reduction and refinement. (S2)
\end{abstract}

Both Dutch animal testing law and AEC-applications seemed to recognize the liveliness of (certain) nonhuman animals in general and of XPA-mice in particular by recognizing their ability to suffer and even designing experiments to reduce animal use and suffering. At the same time, the object status of nonhuman animals remained stable. Even if reducing animal suffering was an important motivation for these experiments, the use of nonhumans (but not humans) for human benefit when deemed necessary by humans was not questioned. On the level of the law, nonhuman animals legally are still property like cars and cages, only humans are legal subjects (cf. Meijer 2016).

Practices of making and enacting laws that separate humans and nonhumans as subjects and objects, do not reflect a pre-existing human-subject and nonhumanobject, but rather produce and reproduce this boundary, which in turn has consequences for which worlds can and cannot emerge. While the 3Rs and experimental legislation prohibited certain experiments seen as unethical, at the same time they legitimized other experiments, such as the ones with the XPA-mice by deeming them 'ethical'. Analyzing this legal practice as a boundary making practice, we can see how each enactment of the law and the 3 Rs reproduced an animal-object/human-subject boundary, which had consequences for the XPA-mice worlds which could emerge. There was no questioning of the human/animal dichotomy that makes (only) nonhuman animals 'testable' and 'killable' in the first place. Considering the consequences of this for XPA-mice responseability, we can say that within such an anthropocentric regulatory framework and

15 Carcinogeniteit Cresidine en AAF in XPA muis. Proefopzet 199800744, 17/12/1998, p.164 File no. 24748. RIVM Archives, Bilthoven, The Netherlands. 
considering interspecies power relations in general, there was little space within the XPA-mouse choreography for anything else to emerge than the 'XPA-lab mouse' hybrid. ${ }^{16}$

\subsection{Macro-agency}

It will probably come as no surprise to you that no XPA-mice were consulted in the process of approving the experiments on them. Certainly, there was some concern for their suffering and an assumption that they would have preferred not to be experimented on, but the decisions making them 'breedable' and 'killable' were seen as one for humans only to make. They were in other words not recognized as political agents. Representation of nonhuman animals in general is weak and only on human terms. Overall, we can state that nonhuman animals are silenced politically (Kymlicka 2017; Meijer 2016).

If we were to include XPA-mice as political agents with response-abilities on the macro-level, what would this mean for their lives and their relations with humans? What can we do to help bring about a world in which XPA-mouse response-abilities on the micro- and macro-level were not extremely limited or foreclosed? This is of course completely hypothetical and speculative since XPA-mice no longer exist ${ }^{17}$, but now that we have gotten to know them, we can use their case to think through possible avenues of remaking interspecies relations.

Reforms of animal experimentation practices based on a care studies perspective tend to focus on welfare improvements and involving (human) society at large (e.g. Davies et al. 2016; Davies et al. 2018; McLeod \& Hartley 2017; Poort et al. 2013). These proposals question neither the anthropocentrism of current regulations nor the anthropocentrism inherent in the process of making these regulations. Here I would like to argue that the posthumanist ethics of exclusion as proposed by Hollins et al. calls for a more radical remaking of interspecies relations in order to be accountable, not only for worlds that did become, but also for worlds that were foreclosed. I am not saying that 'care' should be thrown out of the window, but rather that we need, as Adams and Donovan (2007) also argue, an ethical approach that looks not only at individual suffering, but also at "the political and economic systems that are causing the

16 By interspecies power relations in general, I refer to the omnipresence of human exceptionalism in popular thinking (Keulartz \& Bovenkerk 2016; Masson \& McCarthy 2016)

17 XPA-mice were never used for regulatory carcinogenicity testing and their breeding was ended. 
suffering" (3).

If we were to be attentive to the needs of XPA-mice, and willing to challenge hierarchies and institutions, we would care for them not by giving them larger cages or killing them 'with care', but by using our human response-ability to help bring about worlds where mice are not breedable or killable, a world where mouse-human relations are non-hierarchical.

One measure often proposed in an effort to end human oppression of other animals is granting animals rights, but this is not unproblematic from a posthumanist perspective.

The 'political turn' joins posthumanist critiques of animal rights discourse as being anthropocentric and problematic for seeing living beings as atomistic individuals rather than relational beings (Meijer 2016; Milligan 2015) Animals (including humans) are relational creatures and "(...) global justice need not and should not imply an absolutist universalism about the application of anti-hierarchical moral ideals" (Wyckoff 2016, 252). Different (groups of) animals have different needs and ways of communication, therefore an interspecies democracy should be pluralistic to include a large variety of voices and ways of including those voices (Meijer 2016).

While problematic, 'animal rights' also has it merits in that it is clear, pragmatic and builds on the idea of human rights, meaning it would not require a complete overthrow of current institutions. Posthumanism on the other hand, while being very helpful in rethinking interspecies relations, is much less pragmatic, something which the urgent situation of billions of nonhuman animals suffering at the hand of humans does call for. Moving towards a non-anthropocentric world might justify taking some steps that could on some level be considered anthropocentric, due to the asymmetrical power relations that we are starting with. If we think about our XPA-mice, granting them rights such as the right not to be experimented on, would obviously entail a great improvement of their lives. And while it may be anthropocentric for humans to decide the rights of mice, ending the property status of XPA-mice and other animals seems to be a necessary (but not sufficient) step towards a non-anthropocentric world (cf. Milligan 2015). If we take our relationship with, and care for, other animals such as XPA-mice as a starting point for making legal changes, this hopefully warrants against more humanist imposition than necessary. As soon as possible, we need to then start including other animals in macro-level political decision making, so they can affect the larger dimensions of their lives and co-shape their relations with humans and other species.

When co-creating new worlds, we need to do this with what Burton \& Brady 
(2016) call 'epistemic humility', meaning we should recognize how being human and living in an anthropocentric world limits what we can know about others who are a different species from us. It means we cannot now say what a non-anthropocentric world would look like for XPA-mice, humans or other animals. We can however take steps towards including nonhuman animals as political agents. We can start to work on interspecies democracies, for example by the sanctuary experiment described by Meijer (2016) and Donaldson and Kymlicka (2011). In such a sanctuary, XPA mice would not only be on equal footing with humans and consequently safe from oppression, it would also be a space where individuals are all equal community members, regardless of species. Crucially, they are all able to co-shape the community, influencing both decisions made (content) and the way these are made (process).

Thinking back to the XPA-mice, we can consider what we could learn from intraacting with them in such a non-hierarchical environment compared to the laboratory environment. In such an environment, their response-abilities (as well as those of the humans interacting with them) would be much less constrained by power relations and regulations. Humans and mice could for example choose to avoid each other altogether, or choose to form close cross-species relations. With respect to democratic interaction, they would be able to 'vote with their feet', since they are not held in a cage. From such small-scale experiments, we can start developing interspecies democratic practices on a larger scale (Meijer 2016). The possibility of experimentation on living beings, regardless of species, would depend on whether or not ways of reaching (interspecies) consent can be developed.

\section{Conclusions}

What we account for has consequences for how we wish to remake human/animal relations and experimental practices. Approaches that foreground entanglement and care, tend to lead to proposals that focus on welfare reforms, leaving interspecies power relations in place and human exceptionalism in law making/political processes unchallenged. By analyzing both micro and macro response-abilities of the XPA-mice as consequences of the agential cuts enacted in laboratory and law, I hope to have shown that a post-anthropocentric ethics requires new boundary making practices, that start to deconstruct hierarchies and thereby open up space for nonhuman agency in both the smaller and larger dimensions of nonhuman lives.

Remaking interspecies relations requires more than imaginations of worlds that we want to emerge, it also compels us to think about the practical steps that need 
to be taken to get from where we are now to where we want to end up. As regulations play an important role in legitimizing the use of other animals, it seems logical to want to make changes on the regulatory level. This brings attention to the tensions between regulatory and posthumanist frameworks as both are based on very different conceptions of agency. Where a humanist animal rights framework would not require changing the atomistic concept of agency in regulations (just an expansion towards nonhumans), a posthumanist remaking of regulations would, making it a much greater practical challenge and a remaking with far greater implications. As discussed, a posthumanist remaking requires remaking not only the content of regulations, but also how these regulations are made. The democratic process from which regulations emerge is now a solely human endeavor. ${ }^{18}$ Ways need to be found to involve other animals in this democratic process to do justice to their macro-agency potential. Ideally this would be done through direct representation of other animals in multispecies democratic decision making, such as described in the sanctuary experiment. However, since our current political system is not yet well equipped for his, indirect representation via humans seems to be a more pragmatic way to start moving towards non-hierarchical interspecies relations (e.g. by advocating for ending the property status of nonhuman animals). At the same time we should work on learning to listen to other animals and on recognizing their political acts, so that we can develop more inclusive democratic practices. The dominant position of humans means that we have a great responsibility to change democratic practices and regulations, not to determine which worlds will emerge and which will be foreclosed, but do what we can within our response-ability to bring about worlds where members of different species co-shape both interspecies relations and how we govern these relations.

\section{REFERENCES}

Adams, Carol J. and Josephine Donovan. 2007. The Feminist Care Tradition in Animal Ethics. New York: Columbia University Press.

Arluke, Arnold B. 1988. "Sacrificial Symbolism in Animal Experimentation: Object or Pet?" ResearchGate 2 (2): 98-117. https://doi.org/10.2752/089279389787058091.

Barad, Karen. 2007. Meeting the Universe Halfway: Quantum Physics and the Entanglement of Matter and Meaning. Durham, NC, [etc.]: Duke University Press.

18 Here it is important to be mindful that not every human counts as human in every context. There are of course many examples where certain humans are dehumanized and silenced politically, further emphasizing that 'human' is emergent rather than pre-existing interactions. 
Benson, Etienne. 2011. "Animal Writes: Historiography, Disciplinarity, and the Animal Trace." Making Animal Meaning, 3-16.

Birke, Lynda, Mette Bryld, and Nina Lykke. 2004. "Animal Performances." Feminist Theory 5 (2): 167-83. https://doi.org/10.1177/1464700104045406.

Burton, Simon, and Emily Brady. 2016. "What Is It Like to Be a Bird? Epistemic Humility and Human-Animal Relations." In Animal Ethics in the Age of Humans: Blurring Boundaries in Human-Animal Relationships, edited by Bernice Bovenkerk and Jozef Keulartz, 89-101. The International Library of Environmental, Agricultural and Food Ethics. Cham: Springer International Publishing. https://doi.org/10.1007/978-3319-44206-8_6.

Davies, Gail. 2013. "Mobilizing Experimental Life: Spaces of Becoming with Mutant Mice." Theory, Culture \& Society 30 (7-8): 129-53. https://doi. org/10.1177/0263276413496285.

Davies, Gail F., Beth J. Greenhough, Pru Hobson-West, Robert G. W. Kirk, Ken Applebee, Laura C. Bellingan, Manuel Berdoy, et al. 2016. "Developing a Collaborative Agenda for Humanities and Social Scientific Research on Laboratory Animal Science and Welfare." PLOS ONE 11 (7): e0158791. https://doi.org/10.1371/journal. pone.0158791.

Davies, Gail, Beth Greenhough, Pru Hobson-West, and Robert G. W. Kirk. 2018. "Science, Culture, and Care in Laboratory Animal Research: Interdisciplinary Perspectives on the History and Future of the 3Rs." Science, Technology, \& Human Values 43 (4): 603-21. https://doi.org/10.1177/0162243918757034.

Donaldson, Sue., and Will Kymlicka. 2011. Zoopolis: A Political Theory of Animal Rights. Oxford: Oxford University Press.

Druglitrø, Tone. 2018. "'Skilled Care' and the Making of Good Science." Science, Technology, \& Human Values 43 (4): 649-70. https://doi.org/10.1177/0162243916688093.

Friese, Carrie, and Joanna Latimer. 2019. "Entanglements in Health and Well-Being: Working with Model Organisms in Biomedicine and Bioscience." Medical Anthropology Quarterly 33 (1): 120-37. https://doi.org/10.1111/maq.12489.

Giraud, Eva, and Gregory Hollin. 2016. "Care, Laboratory Beagles and Affective Utopia." Theory, Culture \& Society 33 (4):27-49. https://doi.org/10.1177/0263276415619685.

Greenhough, Beth, and Emma Roe. 2018. "Exploring the Role of Animal Technologists in Implementing the 3Rs: An Ethnographic Investigation of the UK University Sector." Science, Technology, \& Human Values 43 (4): 694-722. https://doi. org/10.1177/0162243917718066.

-_- 2019. "Attuning to Laboratory Animals and Telling Stories: Learning Animal Geography Research Skills from Animal Technologists." Environment and Planning D: Society and Space 37 (2): 367-84. https://doi.org/10.1177/0263775818807720. 
Guerrini, Anita. 2016. "Deep History, Evolutionary History, and Animals in the Anthropocene." In Animal Ethics in the Age of Humans: Blurring Boundaries in Human-Animal Relationships, edited by Bernice Bovenkerk and Jozef Keulartz, 2537. The International Library of Environmental, Agricultural and Food Ethics. Cham: Springer International Publishing. https://doi.org/10.1007/978-3-319-44206-8_2.

Haraway, Donna. 2008. When Species Meet. Minneapolis: Minnesota University press.

Hollin, Gregory, Isla Forsyth, Eva Giraud, and Tracey Potts. 2017. "(Dis)Entangling Barad: Materialisms and Ethics." Social Studies of Science 47 (6): 918-41. https://doi. org/10.1177/0306312717728344.

Irvine, Leslie. 2001. "The Power of Play." Anthrozoös 14 (3): 151-60. https://doi. org/10.2752/089279301786999454.

Keulartz, Jozef, and Bernice Bovenkerk. 2016. "Changing Relationships with NonHuman Animals in the Anthropocene-An Introduction." In Animal Ethics in the Age of Humans: Blurring Boundaries in Human-Animal Relationships, edited by Bernice Bovenkerk and Jozef Keulartz, 1-22. The International Library of Environmental, Agricultural and Food Ethics. Cham: Springer International Publishing. https://doi. org/10.1007/978-3-319-44206-8_1.

Kirk, Robert G. W. 2018. "Recovering The Principles of Humane Experimental Technique: The 3Rs and the Human Essence of Animal Research." Science, Technology, \& Human Values 43 (4): 622-48. https://doi.org/10.1177/0162243917726579.

Kreijl, Coen F. van, Peter A. McAnulty, Rudolf B. Beems, An Vynckier, Harry van Steeg, Ronny Fransson-Steen, Carl L. Alden, Roy Forster, Jan-Willem van der Laan, and John Vandenberghe. 2001. "Xpa and Xpa/P53 +/- Knockout Mice: Overview of Available Data." Toxicologic Pathology 29 (5): 117-27. https://doi. org/10.1080/019262301753178528.

Kymlicka, Will, [Review] Robert Garner and Siobhan O'Sullivan (eds). The Political Turn in Animal Ethics. Rowman and Littlefield, 2016., Animal Studies Journal, 6(1), 2017, 175-181.

Masson, Jeffrey Moussaieff, and Susan McCarthy. 2016. "Unfeeling Brutes." In Animal Ethics in the Age of Humans: Blurring Boundaries in Human-Animal Relationships, edited by Bernice Bovenkerk and Jozef Keulartz, 103-18. The International Library of Environmental, Agricultural and Food Ethics. Cham: Springer International Publishing. https://doi.org/10.1007/978-3-319-44206-8_7.

McLeod, Carmen, and Sarah Hartley. 2017. "Responsibility and Laboratory Animal Research Governance." Science, Technology, \& Human Values 43 (4): 723-41. https:// doi.org/10.1177/0162243917727866.

Meijer, Eva. 2016. "Interspecies Democracies." In Animal Ethics in the Age of Humans: Blurring Boundaries in Human-Animal Relationships, edited by Bernice Bovenkerk and 
Jozef Keulartz, 53-72. The International Library of Environmental, Agricultural and Food Ethics. Cham: Springer International Publishing. https://doi.org/10.1007/9783-319-44206-8_4.

Milligan, Tony. 2015. "The Political Turn in Animal Rights." Politics and Animals 1 (1): 6-15.

Pijnappel, M. C. 2016. Lost in Technification: Uncovering the Latent Clash of Societal Values in Dutch Public Policy Discourse on Animal-Testing Alternatives. [S.I. : s.n.]. https://repository.ubn.ru.nl/handle/2066/151524.

Poort, Lonneke, Tora Holmberg, and Malin Ideland. 2013. "Bringing in the Controversy: Re-Politicizing the de-Politicized Strategy of Ethics Committees." Life Sciences, Society and Policy 9 (1): 11. https://doi.org/10.1186/2195-7819-9-11.

Rader, Karen A. 2004. Making Mice: Standardizing Animals for American Biomedical Research, 1900-1955. Princeton: Princeton University Press.

Ritvo, Harriet. 2007. “On the Animal Turn.” Daedalus 136 (4): 118-22.

Schiffelers, M. J. W. A. 2016. “Animal Testing, 3R Models and Regulatory Acceptance: Technology Transition in a Risk-Averse Context." Dissertation. June 17, 2016. http:// dspace.library.uu.nl/handle/1874/334103.

Twine, Richard. 2010a. "Genomic Natures Read through Posthumanisms." The Sociological Review 58 (1_suppl): 175-95. https://doi.org/10.1111/j.1467954X.2010.01917.x.

Twine, Richard. 2010b. Animals As Biotechnology : Ethics, Sustainability and Critical Animal Studies. London: Earthscan.

Vries, A. de. 1997. "Carcinogenesis in XPA-Deficient Mice." [Utrecht: Universiteit Utrecht].

Wolfe, Cary. 2009. "Human, All Too Human: 'Animal Studies' and the Humanities." PMLA 124 (2): 564-75.

Woods, A. 2017. "Animals and the Shaping of Modern Medicine - One Health and Its Histories" Palgrave Macmillan. Accessed January 30, 2019. //www.palgrave.com/br/ book/9783319643366.

Wyckoff, Jason. 2016. "Hierarchy, Global Justice, and Human-Animal Relations." Journal of International Wildlife Law \& Policy 19 (3): 236-55. https://doi.org/10.1080/1 3880292.2016 .1204884$. 